\title{
La movilidad social de las naciones extranjeras en las ciudades andalu- zas bajomedievales: los Adorno y la sociedad política de Jerez de la Frontera (1470-1520)*
}

\author{
Enrique José Ruiz Pilares ${ }^{1}$ \\ Universidad de Cádiz \\ enrique.pilares@uca.es \\ José Antonio Mingorance Ruiz ${ }^{2}$ \\ Universidad Pablo de Olavide \\ jaminru@hotmail.com
}

RESUMEN: Andalucía contaba a finales del medievo con una posición estratégica en las rutas de navegación entre el Atlántico y el Mediterráneo que estimuló el asentamiento de importantes comunidades mercantiles foráneas. Aunque la historiografía ha puesto de relieve que estos contactos produjeron transformaciones de indole social en estos espacios, son escasos los estudios dedicados a la incorporación de estos colectivos en el seno de las instituciones de poder municipal. En este trabajo profundizamos en esta cuestión a través del estudio de Jerez de la Frontera y la familia genovesa de los Adorno. Tomando como fuente principal los fondos de su Archivo Municipal, se han reconstruido el origen y las bases de su poder socioeconómico y político, así como detalles relevantes sobre su

* Este trabajo forma parte del proyecto de investigación, financiado por el Ministerio de Educación, que lleva por título «El mar como frontera. Transgresiones legales en el Atlántico bajomedieval», referencia PGC2018-095719-B-I00, HAR2013-48433-c2-2-p.

Abreviaturas utilizadas: Archivo Municipal de Jerez de la Frontera, Jerez de la Frontera (AMJF), Actas Capitulares, (AC); Archivo Histórico Nacional, Madrid (AHN), Órdenes Militares, (OM); Archivo General de Simancas, Simancas, Valladolid (AGS), Registro General del Sello, (RGS); Archivo de la Real Chancillería de Granada, Granada (ARCHGR); Real Academia de la Historia, Madrid (RAH); Archivo Histórico de Protocolos Notariales de Jerez de la Frontera, Jerez de la Frontera, Cádiz (AHPNJF).

1 ORCID iD: https://orcid.org/0000-0002-8624-0667.

2 ORCID iD: https://orcid.org/0000-0002-3398-3678.

Copyright: (C) 2019 CSIC. Este es un artículo de acceso abierto distribuido bajo los términos de una licencia de uso y distribución Creative Commons Reconocimiento 4.0 Internacional (CC-BY 4.0) 
integración a través de la construcción de suntuosos enterramientos y políticas matrimoniales. Hemos corroborado cómo una rica familia de mercaderes podía llegar a la cúspide del poder municipal si invertía adecuadamente los beneficios de sus actividades en la compra de oficios de gobierno, propiedades rústicas e inmobiliarias $y$, sobre todo, rentables enlaces con las antiguas familias dirigentes.

PAlabras ClaVE: extranjeros; genoveses; movilidad social; sociedad política; Andalucía; Jerez de la Frontera.

The social mobility of foreign nations in late medieval Andalusian cities: the Adorno family and the political society of Jerez de la Frontera (1470-1520)

ABSTRACT: In the late Middle Ages, Andalusia had a strategic position on the navigation routes between the Atlantic and the Mediterranean which encouraged settlement in major foreign merchant communities. Although historiography has shown that these contacts led to social transformations in these spaces, there are few studies dedicated to these groups' incorporation into municipal power institutions. In this work, we explore the issue by studying the Genoese Adorno family and the town of Jerez de la Frontera. With particular reference to its Municipal Archive, the origin and bases of their socioeconomic and political power have been reconstructed, as have relevant details on their integration by means of the construction of sumptuous burials and marriage policies. We can corroborate that it was possible for a wealthy merchant family to reach the peak of municipal power if they adequately invested the profits of their activities in the purchase of government offices, rural property and real estate and, above all, cultivated advantageous links with former ruling families.

KEY WORDS: foreigners; Genoese; social mobility; political society; Andalusia; Jerez de la Frontera.

CÓMO CITAR ESTE ARTÍCULO/CITATION: Ruiz Pilares, Enrique José y Mingorance Ruiz, José Antonio, «La movilidad social de las naciones extranjeras en las ciudades andaluzas bajomedievales: los Adorno y la sociedad política de Jerez de la Frontera (1470-1520)», Hispania, 79/263 (Madrid, 2019): 669-698. https://doi.org/10.3989/hispania.2019.016.

\section{INTRODUCCIÓN}

La presencia de comunidades extranjeras en las ciudades andaluzas es un hecho constatado con anterioridad a las conquistas realizadas en la cuenca del Guadalquivir por las huestes cristianas en el siglo XIII. Una realidad que se consolidó con el transcurrir de los siglos bajomedievales ${ }^{3}$. Entre los principales

\footnotetext{
3 PAGANI, 2015.
}

Hispania, 2019, vol. LXXIX, nº 263, septiembre-diciembre, págs. 669-698, ISSN: 0018-2141, e-ISSN: 1988-8368 https://doi.org/10.3989/hispania.2019.016 
colectivos foráneos - bretones, ingleses o flamencos-, la nación genovesa, según la terminología de la época, fue sin lugar a dudas la más importante tanto a nivel demográfico, socioeconómico como político ${ }^{4}$. La mayor zona de concentración de esta nación fue el reino de Sevilla, especialmente en su capital y en el entorno de la Bahía de Cádiz ${ }^{5}$. No obstante, como el resto de comunidades extranjeras, sus integrantes mantuvieron en la mayoría de las ocasiones su condición de estante - transeúnte - , no integrándose en la sociedad local más allá de sus intereses económicos en la región ${ }^{6}$.

Según los últimos estudios, a comienzos del siglo XVI solo un $10-15 \%$ de los genoveses se asentaban definitivamente en Andalucía, «elevándose a más del doble en la Bahía de Cádiz, con Cádiz a la cabeza», un caso excepcional debido a su posición estratégica como escala imprescindible de las rutas marítimas, como recientemente ha señalado Raúl González Arévalo ${ }^{7}$. Entre los que tomaron vecindad en la región, nos interesa el análisis de los que ascendieron socialmente y se integraron en las sociedades políticas urbanas, un porcentaje ínfimo, pero con gran impacto en el desarrollo del territorio ${ }^{8}$. En esta realidad, la citada Cádiz se erigía de nuevo como una excepcionalidad, ya que fue la única ciudad donde la incorporación de extranjeros en sus órganos de gobierno no solo fue habitual, sino que monopolizaba los resortes del concejo, como mínimo, desde mediados de la decimoquinta centuria ${ }^{9}$. En el resto de las ciudades de la comarca, este proceso fue mucho más limitado y tardío, como ya apuntaba hace bastantes años Sancho de Sopranis ${ }^{10}$. Conclusiones similares podemos observar en los procesos de integración en los gobiernos urbanos de otras grandes ciudades del entorno como Sevilla, Málaga o Granada — al igual que en el resto de Castilla—, donde los intereses económicos y la integración y movilidad social rara vez fueron de la mano ${ }^{11}$.

En Jerez, la presencia de algunas familias ligures está documentada desde fechas muy tempranas - Zaccaría o Pessagno en el XIII-, pero hasta la segunda mitad del XV no empezaron a ser relevantes numérica y políticamente $^{12}$. En el año de 1490 se han documentado 83 genoveses en la ciudad: 41

${ }^{4}$ La bibliografía sobre el tema ha sido muy prolífica en los últimos años. Sobre la cronología, causas y motivos de su asentamiento y su localización, nos remitimos al reciente estado de la cuestión realizado por GONZÁLEZ ARÉVALO, 23 (Madrid, 2013): 175-208.

5 D'ARIENZO, 1993, vol. 3: 133-183.

${ }^{6}$ BELLO LEÓN, 1994.

7 GONZÁLEZ ARÉVALO, 2016a: 400.

${ }^{8}$ HEERS, 1982: 419-444. GONZÁLEZ ARÉVALO, 2016a: 376.

9 MARTÍN GUTIÉRREZ, 29 (Madrid, 2006): 187-223. SÁNCHEZ HERRERO, 1986: 189-197.

10 SANCHO DE SOPRANIS, VIII (Madrid, 1948): 353-402.

11 LÓPEZ DE COCA y LÓPEZ BELTRÁN, 7 (Sevilla, 1980).

12 No es descartable que algún miembro de la familia Adorno se asentase en esos años. Un tal Doménico Adorno aparece entre los primeros repobladores de Cádiz. Es probable que se trate del mismo personaje que, según la tradición, trajo la primigenia imagen de la Virgen de la Consolación al convento de Santo Domingo de Jerez en 1285, RÍOS TOLEDANO (Cádiz, 2019). 
vecinos y 42 estantes. A esas alturas era incontestable el rol de los ligures como principales exportadores e importadores de la comarca, contando con sólidos lazos económicos con los mercaderes-artesanos locales, intermediarios en muchos de sus negocios ${ }^{13}$.

Una cuenta de mercaderes elaborada por los almojarifes jerezanos en 1502 confirma la relevancia de los genoveses como principales importadores de mercancías $^{14}$. Martín Spínola, integrante de uno de los linajes ligures más poderosos, aparece en primer lugar con un protagonismo indiscutible, con variadas importaciones - cuero, papel, hilo, seda y tejidos flamencos-que rondaban los dos millones de maravedíes. Su familia era la más consolidada en la ciudad, como en el resto de la bahía y buena parte de Andalucía en el siglo $\mathrm{XV}^{15}$. Sus mercancías procedían de los principales mercados europeos: los paños de Flandes, el cuero de Irlanda, el acero vasco, etc. Para los genoveses, la Bahía de Cádiz fue la base de operaciones y centro redistribuidor de las manufacturas del norte de Europa, el oro y los esclavos africanos, o el azúcar de Canarias y Madeira ${ }^{16}$. En uno de los primeros puestos del mencionado documento aparece la figura de Giacomo Adorno, con importaciones que rondaban los 150.000 maravedíes - especialmente cuero, lana, acero y grana-. En esas fechas, su familia ya había conseguido lo que los Spínola llevaban intentando sin éxito durante décadas, integrarse en el grupo dirigente jerezano ${ }^{17}$.

El estudio de esta familia jerezana viene a completar una nómina de casos de estudio similares que en los últimos años han arrojado mucha luz sobre los procesos de integración y ascenso social de los extranjeros en las ciudades andaluzas, como es el caso de los Font y Benavent catalanes en la Bahía de Cádiz, o los Centurión e Ytalian genoveses en Málaga, entre otros ${ }^{18}$.

\section{LA INTEGRACIÓN EN LA SOCIEDAD POLÍTICA JEREZANA}

Los orígenes de los Adorno fueron muy modestos. Parece que procedían de una familia de artesanos de la lana de una pequeña localidad de la costa ligur llamada Taggia, a un centenar de kilómetros al oeste de Génova. A esta ciudad

13 MINGORANCE RUIZ, 2013: 131-143.

14 AGS, Escribanía Mayor de Rentas, 80/2, ff. 212r-252v. Agradecemos al profesor Emilio Martín Gutiérrez que nos haya facilitado la consulta de este documento.

15 SÁNCHEZ SAUS, 1996: 309-311. FÁBREGAS GARCÍA, 2002. GONZÁLEZ ARÉVALO, 2016b: 249-273; 15-2 (2013): 1-22.

16 BELLO LEÓN, 1995: 79.

17 FRANCO SILVA y CRUZ MARIÑO, 35 (Madrid, 2012): 306. MINGORANCE RUIZ, 2013: 1677-1683. SÁNCHEZ SAUS, 1996: 163-164.

${ }_{18}$ BELLO LEÓN, 40/1 (Barcelona, 2010). LÓPEZ DE COCA y LÓPEZ BELTRÁN, 7 (Sevilla, 1980).

Hispania, 2019, vol. LXXIX, nº 263, septiembre-diciembre, págs. 669-698, ISSN: 0018-2141, e-ISSN: 1988-8368 https://doi.org/10.3989/hispania.2019.016 
se trasladaron algunos de sus miembros en la segunda mitad del siglo XIII ${ }^{19}$, dedicándose a los negocios mercantiles y bancarios, actividades que permitieron a Lanfranco Adorno, en 1261, ser elegido como anciano del Consejo Ciudadano de la República ${ }^{20}$. En las siguientes décadas, fueron consolidando su influencia política hasta convertirse en uno de los principales alberghi ${ }^{21}$ popolari - compuestos por artesanos y mercaderes - que apoyaron en 1339 a Simón Boccanegra como primer $d u x$ vitalicio de esta ciudad-estado. Con esta maniobra desplazaron del poder a los linajes nobili, que venían gozando, desde al menos el siglo XII, del control del Consejo de Ancianos y el Consulado, y cuya base originaria de poder se asentaba en la tierra y en la posesión de feudos ${ }^{22}$.

A la muerte de Boccanegra en 1363, los nobili ya habían sido expulsados de las instituciones políticas, quedando el control del dogato - la institución política más importante de la República - en manos de los dos principales clanes popolari de la ciudad, los Adorno y los Fregoso. Ambas familias se relevaron en el poder a través de luchas intestinas auspiciadas por el resto de principales personajes y linajes de la ciudad y toda una serie de potencias exteriores Milán, Francia o Aragón-que intentaron influenciar en el gobierno ${ }^{23}$. Esta situación se mantuvo hasta 1528, cuando se reorganizó el sistema político de la República y ambos linajes fueron excluidos del poder ${ }^{24}$.

El clima de tensión que vivía Génova, marcado por constantes revueltas, enfrentamientos y destierros, explica en parte la emigración de algunas ramas de los Adorno a otras partes del continente europeo ${ }^{25}$. La escasez de territorio y la debilidad del grupo dirigente - fenómeno contrario a lo ocurrido en repúblicas en pleno proceso de expansión como Venecia o Florencia-, es otra de

${ }^{19}$ Con posterioridad, las genealogías familiares intentaron encubrir su procedencia humilde, recreando una ascendencia más ilustre y digna de la posición que alcanzaron, vinculando sus orígenes a la nobleza germánica, PETTI BALBI, 1991: 218-223.

${ }^{20}$ CHIAVARI CATTANEO DELLA VOLTA, 2002: 11-30.

${ }^{21}$ El albergo era un sistema de reproducción social particular de la República de Génova basado en la agrupación bajo un mismo apellido de toda una serie de familias unidas por lazos de sangre, económicos, de amistad, etc. que vivían en la misma zona o distrito del núcleo urbano y sus alrededores, LEVEROTTI, 2005: 92-94. Véase también HEERS, 1981: 419-444.

${ }^{22}$ No obstante, desde mediados del siglo XIV era un grupo heterogéneo integrado también por muchas familias mercantiles que habían alcanzado la consideración de nobleza. Una síntesis sobre el conflicto entre popolari y nobili y los cambios de gobierno en la República en EPSTEIN, 1996: 188-227.

${ }^{23}$ Un análisis detallado sobre el contexto sociopolítico que vivieron los Adorno en Génova en MUSSO, 2005: 523-561. Véase también PETTI BALBI, 1991b.

${ }^{24}$ Los Adorno y los Fregoso perdieron el privilegio de constituirse como Albergo y no fueron incluidos en el Libro d'oro della nobiltà. En el caso de los Adorno, se integraron en el de los Pinelli, CHIAVARI CATTANEO DELLA VOLTA, 2002: 115.

${ }^{25}$ «Si erano transfirito in Spagna, specialmente nel momento in cui le lote instentine prima, e la reforma di Andrea Doria (1528) poi, avevano reso insostenibile la permanezza a Genova dei personaggi piu compromessi», CHIAVARI CATTANEO DELLA VOLTA, 2002: 47-48. 
las razones principales que explican el interés de la comunidad genovesa por integrarse en otros espacios europeos ${ }^{26}$. A ello se unía el aumento progresivo del interés comercial hacia las rutas atlánticas, tras el progresivo cierre de los mercados orientales con el avance de los turcos otomanos. Entre los siglos XIV y XV hay constancia del asentamiento de diferentes ramas de la familia en Francia, el Imperio alemán, Portugal, pero sobre todo Castilla y Flandes ${ }^{27}$.

En el caso castellano, el principal lugar de asentamiento estable de integrantes de esta familia fue Jerez de la Frontera ${ }^{28}$. En 1477, aunque debía llevar ya algunos años negociando en la comarca, aparece por primera vez en la documentación castellana el mercader genovés Francesco Adorno como estante en la ciudad ${ }^{29}$. Hijo del comerciante y consejero del consejo de la república Giacomo Adorno di Medialuce, era descendiente directo del dux Gabriele Adorno (1363-1370) ${ }^{30}$. Al menos desde comienzos de la década de 1470 este personaje debía contar con contactos sólidos en la comarca, bajo el amparo de Rodrigo Ponce de León, marqués de Cádiz, señor de los núcleos costeros de Rota y Chipiona, y corregidor de Jerez. En esas fechas, en las que Francesco se desposó con la andaluza Catalina de Figueroa ${ }^{31}$, se convirtió en contador, proveedor y prestamista de los Ponce de León, quienes les favorecieron y protegieron en sus negocios mercantiles ${ }^{32}$. Francesco estuvo acompañado en esta aventura por su hermano Lorenzo - que alternó sus negocios entre Sevilla y Jerez ${ }^{33}$ - y su hermano menor Giacomo, que no alcanzará protagonismo en la ciudad hasta comienzos del siglo $\mathrm{XVI}^{34}$.

${ }^{26}$ GONZÁLEZ ARÉVALO, 2016: 401.

27 CHIAVARI CATTANEO DELLA VOLTA, 2012: 99-129. Sobre la comunidad asentada en Flandes, la más importante de todas, y cuyas referencias se remiten a finales del siglo XIII, nos remitimos a PETTI BALBI, 1996: 21-46.

28 Aunque sus negocios en otras ciudades cercanas han sido datados con anterioridad (este es el caso de Luca Batista Adorno o Simone Adorno en Sevilla en 1467), no hay referencias concretas de su establecimiento hasta la década de 1490. Es el caso de los acomodados comerciantes como Juan Bautista, Ambrosio y, especialmente, el mencionado Luca Batista Adorno, que llegó a ser cónsul de los genoveses en Sevilla a inicios del siglo XVI, OTTE SANDER, 1996: 135. BELLO LEÓN, 1994; 41 (Sevilla, 2014): 35.

${ }^{29}$ MINGORANCE RUIZ, 2013: 1055-1507. BELLO LEÓN, 41 (Sevilla, 2014): 33-34.

${ }^{30}$ LITTA, 1849, familia 4.

31 Es probable que perteneciese a una de las familias sevillanas más importantes de la época, vinculada a los Ponce de León. Puede comprobarse la presencia de diferentes mujeres que portaban este apellido en la obra genealógica de SÁNCHEZ SAUS, 1991: 208, 226 y 237.

32 A modo de ejemplo, en el citado año de 1477 la marquesa Beatriz Pacheco solicitó que le perdonasen por exportar 200 cahíces de trigo sin licencia regia, AGS, RGS, leg. 1477-10, f. 102. Entre las cuantías más destacadas, prestó a Juan Ponce de León, hermano del Marqués, 100.000 maravedíes, que aún le eran debidos a sus herederos en 1507, AHPNJF, 1507, escribano Sebastián Gaitán, f. 407v.

33 BELLO LEÓN, 1994: 108.

${ }^{34}$ La historiografía, basada con total seguridad en genealogías genovesas erróneas — de las que se hace eco por ejemplo CHIAVARI CATTANEO DELLA VOLTA, 2012: 114-119- 
Cuando el marqués perdió el gobierno de Jerez a finales de 1477, Francesco pasó a convertirse en su hombre de confianza en la ciudad. Aunque ya era un personaje reconocido por sus negocios y su solvencia económica - fue designado como cambiador por el concejo en $1482{ }^{35}$, era consciente de la necesidad de conseguir un puesto en la asamblea concejil para participar de las decisiones del principal órgano rector de la vida pública de las ciudades castellanas bajomedievales. A diferencia de lo que ocurría en su Génova natal y en otras regiones de Europa, como Inglaterra, Alemania, Flandes o Aragón, la presencia de mercaderes no era frecuente en las instituciones concejiles del reino, donde la vida fronteriza frente a los poderes musulmanes había generado un estamento caballeresco que se había reservado el control de los gobiernos urbanos a base de toda una serie de prerrogativas y privilegios ${ }^{36}$. La propiedad de tierras, el control de amplios rebaños o el ejercicio de las armas otorgaban cierta homogeneidad a sus élites ${ }^{37}$.

Centrándonos en el caso que nos ocupa, Jerez de la Frontera fue, desde su conquista por las tropas cristianas hasta la caída de Granada en 1492, una ciudad fronteriza. Ello se tradujo en el liderazgo de linajes caballerescos vinculados al servicio de las armas. Las actividades agropecuarias, vinculadas íntimamente a su modo de vida fronterizo, tuvieron un papel primordial en la composición de sus patrimonios. Esto no significaba que personajes y familias enriquecidas con los negocios artesanales o mercantiles no pudiesen ingresar en el grupo dirigente ${ }^{38}$, pero para ello tuvieron que asimilar prácticas y valores vinculados al mundo de la caballería ${ }^{39}$, así como la inversión en la compra de tierras, la estructuración en linajes, la certificación de la nobleza de sangre, la posesión de señoríos, o el servicio de la Corona y a la nobleza territoria ${ }^{40}$.

La sociedad política jerezana ${ }^{41}$ estaba formada a finales del siglo XV por una veintena de familias o linajes familiares ${ }^{42}$. El control de los principales

señalaban a este personaje como el primero de los miembros de esta familia en Jerez, fechando su muerte en 1455. La documentación notarial jerezana descarta por completo esta posibilidad, retrasando la llegada de Giacomo, en el mejor de los casos, a la década de 1490, BELLO LEÓN, 41 (Sevilla, 2014): 35.

35 Sustituyó en el oficio a su compatriota Cristóbal Regina, BELLO LEÓN, 41 (Sevilla, 2014): 24.

36 BOUCHERON y MENJOT, 2011: 323-333.

${ }^{37}$ LADERO QUESADA, 5 (Madrid, 1986): 558. VALDEÓN BARUQUE, 1990: 510-511.

38 RUCQUOI, 1994: 361-662.

39 «El burgués enriquecido aspiraba a ser admitido en los rangos de la nobleza urbana», VALDEÓN BARUQUE, 1990: 516. Varios casos de estudio en ASENJO GONZÁLEZ, 2013.

${ }^{40}$ MONSALVO ANTÓN, 1990: 398. VAL VALDIVIESO, 17 (Madrid, 1994): 158.

${ }^{41}$ Sobre la aplicación del concepto «sociedad política» al análisis de los diferentes grupos y espacios de poder en las ciudades bajomedievales ver SÁNCHEZ SAUS, 2009: 19-20.

${ }^{42}$ En el contexto andaluz bajomedieval, la voz «linaje» se refería a familias nucleares estrechamente vinculadas, descendientes de un mismo tronco familiar, MONSALVO ANTÓN, 53/185 (Madrid, 1993), 948-950. Su símbolo identificativo era el apellido, SÁNCHEZ SAUS, 1991. 
oficios del concejo - regimiento y juradurías - era el elemento definitorio de este grupo dirigente ${ }^{43}$, esta «élite concejil»» ${ }^{44}$. El cuerpo de regidores -25 en Jerez en esos años- era el más importante de todos. Con derecho a voz y voto, era el puesto anhelado por todas las personas influyentes de la ciudad. En palabras de José María Monsalvo, «la pertenencia al mismo [regimiento] se convirtió indudablemente en un sesgo de distinción entre la minoría de gobierno patricia y el resto» ${ }^{45}$. Por su parte, los jurados — una veintena-, solo tenían derecho a elevar su opinión ante el resto de compañeros, pero el simple derecho de asistir a las reuniones era un honor nada despreciable ante los limitados puestos existentes en el regimiento ${ }^{46}$. Acceder a los órganos de gobierno era una condición sine qua non para instalarse en la cúspide sociopolítica. Para Yolanda Navarrete, el poder y el estatus social adquirido se materializaba simbólicamente en «la preeminencia que manifestaban y que disfrutaban en todos los actos públicos, incluidas las solemnes procesiones y festejos urbanos», como el Corpus Christi ${ }^{47}$.

Francesco no dudó en invertir parte de su fortuna —en torno a 150.000 maravedíes - en adquirir un puesto de jurado en la asamblea concejil en $1484^{48}$. Esta práctica ilegal, que llegará a su culmen en el siglo XVI, empezaba a hacerse bastante habitual en los concejos del reino ${ }^{49}$, en la que los genoveses no dudaron en participar para conseguir sus objetivos socioeconómicos ${ }^{50}$. A pesar de la inversión realizada, no estuvo muy presente en las reuniones semanales del concejo debido a sus numerosas actividades económicas - por ejemplo, entre 1485 y 1486 fue arrendador de impuestos en nombre del marqués en Cádiz- - ${ }^{51}$. Ello no significó que se despreocupase de sus dos principales áreas de interés prioritarias que justificaban su presencia en el órgano de gobierno de la ciudad: la defensa de las prerrogativas de los comerciantes extranjeros, espe-

43 BERTELLI, 1978: 109.

${ }^{44}$ RUIZ PILARES, 2017: 470-472.

45 MONSALVO ANTÓN, 2013: 168-169. Este autor enumera las principales ventajas anejas al cargo: «Impunidad, aunque fuera relativa; facilidad para legalizar en el concejo usurpaciones, privatizar terrenos o gozar de privilegios relativos a los aprovechamientos agropecuarios [...], otorgar favores y recibir a cambio fidelidad y apoyos decisivos», MONSALVO ANTÓN, 1988: 232.

${ }^{46}$ Sobre este oficio, que en el siglo XIII nació para representar los derechos de los vecinos y que a lo largo del siglo XV se convirtió en otro instrumento de poder en manos de pocas familias, véase MONSALVO ANTÓN, VII (Salamanca, 1989): 60-63.

47 GUERRERO NAVARRETE, 16 (Alicante, 2009-2010): 81.

${ }^{48}$ La designación en AGS, RGS, leg. 1484-12, f. 27. La aceptación en AMJF, AC, 1484, f. 22r.

49 TOMÁS Y VALIENTE, 1970: 125-159.

50 SORIA MESA, 2011: 23. GIRÓN PASCUAL, 2012: 236.

51 Aparece como uno de los responsables económicos de los estados del marqués en las cuentas conservadas para Cádiz en esos años, AHN, OSUNA, 1622, D. 1. Véase también LADERO QUESADA, II-III (Cádiz, 1975): 88.

Hispania, 2019, vol. LXXIX, nº 263, septiembre-diciembre, págs. 669-698, ISSN: 0018-2141, e-ISSN: 1988-8368 https://doi.org/10.3989/hispania.2019.016 
cialmente sus paisanos genoveses ${ }^{52}$, y mejorar las deterioradas relaciones de la élite caballeresca dirigente con la Casa de Arcos, tras más de un lustro de gobierno autoritario del marqués ${ }^{53}$.

Para consolidar su posición preeminente en la vida política jerezana desplegó una sutil política económica y matrimonial que le convirtió en un respetado caballero terrateniente de la ciudad, estrategia que se ha documentado en otras ciudades principales de Andalucía y el reino de Castilla, especialmente desde finales del siglo $\mathrm{XV}^{54}$. En primer lugar, invirtió buena parte de los ingresos generados por sus actividades comerciales y financieras en la compra de tierras y propiedades urbanas: a su muerte, en 1499, poseía, entre otras propiedades, una amplia morada en la calle principal de la ciudad - cal de Fran$\cos$-, más de 300 aranzadas dedicadas al cereal y medio centenar de aranzadas de viñas ${ }^{55}$. Por otro lado, consiguió ventajosos desposorios para sus dos hijos legítimos con vástagos de dos de las familias más importantes de la ciudad. Su primogénito Leonís o Dionís, nacido en Jerez y llamado así en honor al santo patrón de la ciudad - San Dionisio-, fue unido en matrimonio con una hija de Cristóbal Dávila, rico terrateniente perteneciente a una de las dos familias más poderosas de la época ${ }^{56}$. Para su dote, su padre no dudó en comprarle un oficio de regidor por 200.000 maravedíes en $1496^{57}$. Por su parte, su hija María casó con el regidor Pedro Martínez de Hinojosa ${ }^{58}$. Este tipo de alianzas con el grupo dirigente, «les permitieron imbricarse en los círculos de poder» y superar «supuestos rechazos de la sociedad para con los ligures»"

Leonís siguió una trayectoria política y económica similar a su padre: defensa de los derechos de los genoveses en el concejo, servicio a la Casa de Arcos - llegó a ser corregidor de Arcos de la Frontera entre 1516 y 1521 - y una participación activa en la producción y exportación de los productos del agro jerezano. Aunque ya era un caballero jerezano de pleno derecho, sus contactos con su comunidad de origen se mantuvieron sólidos durante toda su vida. A modo de ejemplo, una de sus hijas casó con el mercader genovés Gerónimo Saluzzo ${ }^{60}$. La presencia en la asamblea concejil y los vínculos matrimoniales con las principales familias caballerescas confirman que los Adorno

${ }_{52} \mathrm{Su}$ papel como juez y representante de sus paisanos en la comarca en BELLO LEÓN, 2014: 33-34.

${ }^{53}$ Solo se registra un $8 \%$ de asistencia en los cabildos documentados, AMJF, AC, 14841500.

${ }^{54}$ SORIA MESA, 2011: 23-24; 2007: 173-184. GIRÓN PASCUAL, 3 (Córdoba, 2013): 97.

55 MINGORANCE RUIZ, 2013: 1055-1057.

56 AMJF, AC, 1485, f. 32v.

57 AHPNJF, 1521, Rodrigo de Cuenca f. 173r.

${ }^{58}$ MINGORANCE RUIZ, 2013: 1055-1057.

59 GIRÓN PASCUAL, 2012: 220.

${ }^{60}$ MINGORANCE RUIZ, 2013:1647-1651.

Hispania, 2019, vol. LXXIX, nº 263, septiembre-diciembre, págs. 669-698, ISSN: 0018-2141, e-ISSN: 1988-8368 https://doi.org/10.3989/hispania.2019.016 
se habían situado en pocos años en la cúspide de la sociedad política jerezana. La clave de este tipo de ascensos, en palabras de González Arévalo, fueron «el éxito económico, y en consecuencia el éxito social, [...] condición sine qua non para lograr una mayor integración en las élites locales» ${ }^{61}$.

Junto a los descendientes de Francesco, la otra rama principal de los Adorno jerezanos desciende de su hermano menor Giacomo, que se asentó en la ciudad a finales del siglo XVI. Este personaje, que a diferencia de Francesco no participó directamente en la vida política, se convirtió en pocos años en uno de los personajes más ricos de la ciudad, hasta el punto de emparentar con los dos linajes más poderosos de la ciudad, los Villavicencio - tras casar en torno al año 1500 en primeras nupcias con Ana Núñez de Villavicencio - y con los Dávila - tras desposarse con Isabel Padilla Dávila tras enviudar en 1525- Ese legado económico y social permitirá a su hijo Agustín convertirse en el segundo tercio del siglo XVI en uno de los regidores más influyentes y poderosos ${ }^{62}$.

Los Medialuce Adorno se mantuvieron muy unidos en la ciudad ${ }^{63}$. El mejor ejemplo es el enlace matrimonial entre uno de los nietos de Francesco, de nombre homónimo, con María Adorno, hija de su hermano menor Giacomo $^{64}$. Asimismo, siguieron manteniendo importantes contactos con el resto de sus familiares y su Génova natal. Una hermana de Francesco - María-, permaneció en la república liguria, esposándose con su pariente Luca di Marvello Adorno, que ocupó un puesto en el Consejo de Ancianos en $1494{ }^{65}$. Otra hermana, llamada Andreola, se desposó con Agostino Saluzzo en $1479^{66}$. Su hijo Giacomo, que ocupó algunos oficios menores en Génova, como el de console delle calleghe - encargado de las subastas públicas - en 1516, era el factor de los negocios de su tío homónimo en tierras italianas en la década de $1520^{67}$. Por su parte, su hermano Gerónimo Saluzzo ${ }^{68}$, tras alternar su residencia entre Cádiz y Jerez desde la década de 1510, ya se había asentado en

${ }^{61}$ GONZÁLEZ ARÉVALO, 2016a: 378.

62 MINGORANCE RUIZ, 2013: 1331-1358.

${ }^{63}$ Muchos años después, en 1577, los descendientes de Francesco y su hermano Giacomo se presentaron ante el senado de Génova para solicitar sus prerrogativas como nobles por ser descendientes de «Francesco, Giacomo e Lorenzo Adorno, genovesi che avevano stabilito la propia sede nel regno di Spagna», CHIAVARI CATTANEO DELLA VOLTA, 2002: 115.

${ }^{64}$ MINGORANCE RUIZ, 2012: 1355.

${ }^{65}$ LITTA, 1849, familia 4.

${ }^{66}$ BARALDI, 1845: 143-144.

${ }^{67}$ MINGORANCE RUIZ, 2013: 1335. Esta familia genovesa, asentada en la ciudad en 1438 procedente de la vecina localidad de Bonasola, había alcanzado en pocos años un cierto protagonismo en la vida económica de la ciudad, ocupando cargos de segundo nivel en la administración de la República, ASCIERI, 1846: 72.

${ }_{68}$ Parece que era hijo de la segunda esposa de su padre, Mariola Mandona, debiendo nacer poco después de este matrimonio en 1491, BARALDI, 1845: 144. 
esta última en 1524, tras casar con una de las hijas del regidor Leonís Adorno - Isabel-69.

Otros integrantes de la familia Adorno, sin aparente parentesco directo con esta rama de los Medialuce, comenzaron a asentarse en la ciudad a comienzos del siglo XVI. El primero de ellos fue Esteban Adorno, que ya entablaba negocios en la ciudad en 1518. Al año siguiente, ya se había avecindado y esposado con la genovesa María Cigala. Ambos murieron sin herederos poco tiempo después - en torno a 1522-, quedando el grueso de sus bienes en su padre Gabriel, que seguía viviendo en Génova ${ }^{70}$. En último lugar, sabemos que 1523 hará su aparición por primera vez en la documentación Juan Adorno, de oficio sastre, que se avecindará en la ciudad, donde echará raíces tras desposarse con una tal Ana Núñez ${ }^{71}$.

\section{LAS ACTIVIDADES ECONÓMICAS: UN TERRATENIENTE «A LA GENOVESA»}

Aunque Jerez carece de documentos fiscales - como padrones - que nos permitan reconstruir con detalle la estructura socioeconómica de la población ${ }^{72}$, a tenor de los últimos estudios ha quedado bastante esclarecido el hecho de que las personas y familias más acomodadas pertenecían al grupo caballeresco que lideraba la ciudad. Eso no significaba que algún mercader o artesano enriquecido contase con un patrimonio que pudiese rivalizar con estos, pero se trataba de casos aislados entre los vecinos de la ciudad ${ }^{73}$. Centrándonos en el caso de los Adorno, contamos con un interesante documento, fechado en 1491, que nos permite conocer la posición exacta que gozaba el patrimonio del jurado Francisco Adorno entre sus compañeros del concejo. Su hacienda ocupaba la septima posición en un elenco en el que aparecen buena parte de los oficiales concejiles -27 regidores y jurados- Se trata de un texto generado por los responsables económicos del concejo - mayordomos y contadores - para distribuir la cantidad exacta que cada oficial concejil debía aportar para subsanar una deuda contraída por la ciudad con un delegado regio. El criterio seguido para realizar el reparto fueron los bienes muebles e inmuebles que aparecían en los desaparecidos padrones de bienes - no se incluyeron en el reparto aquellos oficiales que se encontraban sirviendo en la guerra, que, no obstante, no eran los más acaudalados- ${ }^{74}$.

${ }^{69}$ MINGORANCE RUIZ, 2013: 1209-1218.

${ }^{70}$ MINGORANCE RUIZ, 2013: 1025-1028.

71 MINGORANCE RUIZ, 2013: 1408.

72 GONZÁLEZ GÓMEZ, 1982: 35-47.

${ }^{73}$ RUIZ PILARES, 2016: 337-364.

${ }^{74}$ Francesco Adorno contribuyó con 850 maravedíes - 950 fue la cantidad fijada para los más acaudalados - frente a los 200 pagados por los oficiales que contaban con haciendas más precarias. Solo fue superado por personajes de la relevancia de los regidores Pedro Camacho 
A partir de este documento y las referencias parciales a la totalidad de su patrimonio que aparecen en los registros notariales jerezanos, podemos afirmar que su fortuna debío rondar o superar los dos millones de maravedíes a fecha de su muerte - 1499-. Una hacienda que duplicaba el valor medio de los patrimonios del grupo dirigente, aunque no alcanzaba a igualar a la media docena de hombres más ricos de la ciudad, que rondaban o superaban los diez millones ${ }^{75}$. Al origen y bases de este inmenso patrimonio, en torno a la que giró el ascenso social de este linaje genovés y la de sus descendientes en la ciudad, dedicaremos el siguiente apartado.

\section{Las actividades comerciales y financieras}

El origen del patrimonio del jurado Adorno, como el del resto de sus compatriotas genoveses que llegaban diariamente a la costa andaluza, fueron las actividades vinculadas con el comercio y el crédito. Como ya se ha mencionado, el éxito de sus negocios en Jerez y su comarca no puede entenderse sin el favor y protección que gozó del marqués de Cádiz en Jerez - especialmente durante su corregimiento (1471-1477) - y en sus señoríos del entorno - Cádiz, Rota o Arcos, principalmente-. Se benefició, por ejemplo, de su posición como contador, proveedor y prestamista de los Ponce de León, para comprar a precios ventajosos el atún de las almadrabas que estos controlaban en Cádiz hasta que perdieron la ciudad en $1492-{ }^{76}$. Entre otras noticias, sabemos que en 1484 adquirió cierta cantidad valorada en 68.546 maravedíes para revenderla en la comarca ${ }^{77}$, o que le vendió a su paisano Batista Garfio seis barriles repletos de este pescado por 11.700 maravedíes en $1490^{78}$.

Los negocios mercantiles de la familia Adorno, al menos en tiempos de Francisco y su hijo Leonís, estuvieron protagonizados - aunque participaron de otros géneros como el citado atún- por el comercio del vino de la tierra, el producto local más codiciado en los mercados del norte de Europa ${ }^{79}$. El cultivo de la vid, que se remonta en la comarca jerezana hasta la Antigüedad $^{80}$, no

de Villavicencio, Nuño de Villavicencio, Alvar e Iñigo López o el jurado Martín Dávila, AMJF, AC, 1491 ff. 125-126v. Una descripción minuciosa de los ricos patrimonios de dos de estos últimos personajes, que superaban los cinco millones de maravedíes, en SÁNCHEZ SAUS, 18 (Barcelona, 1988): 469-486. RUIZ PILARES, 35 (Madrid, 2012): 315-320.

75 RUIZ PILARES, 35 (Madrid, 2012): 320-332.; 2017: 167.

76 Sobre las almadrabas de la costa gaditana véase BELLO LEÓN, 32 (Sevilla, 2005): 81-113.

77 LADERO QUESADA, II-III (Cádiz, 1975): 11.

78 AHPNJF, 1490, escribano Bartolomé de Maya, f. 357r.

79 RUIZ PILARES, 2016: 337-364.

${ }^{80}$ Lázaro Lagóstena está llevando a cabo un proyecto de investigación para reconstruir los lugares de producción y distribución del vino de la región desde la antigüedad en el Seminario 
empezó a convertirse en el producto que ha dado protagonismo internacional a esta ciudad andaluza hasta el siglo $X^{81}$. En la década de 1480 el concejo elaboró una completa legislación para conseguir una óptima calidad y evitar malos usos en su elaboración ${ }^{82}$. Esta normativa fue clave para que el «Jerez» se convirtiese en un producto de referencia con denominación de origen en los mercados extranjeros ${ }^{83}$. Su exportación era una lucrativa actividad que explica, como detallaremos más adelante, que Francesco adquiriese más de medio centenar de aranzadas dedicadas a vides en Jerez y Chipiona para abaratar los costes.

Con toda probabilidad, este mercader debió realizar varias exportaciones cada año a Flandes, Normandía e Inglaterra en el último tercio del siglo XV. La documentación notarial jerezana solo nos permite seguir su pista en 1484 y 1490 (cuadro 1). También sabemos que Brujas fue otro de sus destinos habituales, lugar donde había entablado varios contactos comerciales ${ }^{84}$. Su criado y factor, su paisano Francisco Airaldo, se encargó durante esos años de custodiar las mercancías durante el viaje. También se encargaba de su venta y de comprar el género demandado por su patrón. En otras ocasiones, Adorno encargaba estas labores a otro mercader, que solía compartir cargamento con él en la misma embarcación. Como ejemplo, en 1490 fletó un barco con destino a Inglaterra. Dos tercios del cargamento - vino y frutas - pertenecían a Adorno, el resto a su paisano Nicoloso de Ceba. Este último estaba al cargo de la venta de todas las mercancías. Adorno tenía la capacidad para fletar importantes cargamentos. Ese mismo año demandó a su factor que contratase los servicios de los maestres de una o dos naos «que sean viscaynas grandes $\rangle^{85}$. Asimismo, aumentaba sus beneficios mediante préstamos a la gruesa a los maestres y proporcionando los alimentos necesarios para el abastecimiento de las embarcaciones. Juan de Ochoa, uno de los maestres vizcaínos contratados para transportar sus mercancías a Flandes, recibió bizcocho valorado en 23.450 maravedíes en 1490 .

Agustín de Horozco de la Universidad de Cádiz. Como ejemplo, podemos citar un reciente trabajo realizado por uno de sus investigadores, a partir de la aplicación de los Sistemas de Información Geográfica para la reconstrucción del paisaje vitivinícola romano: TRAPERO FERNÁNDEZ, 14 (2016): 53-60.

${ }^{81}$ MARTÍN GUTIÉRREZ, 1996: 296-300.

82 CARMONA RUIZ y MARTÍN GUTIÉRREZ, 2010: 324-327. SANCHO DE SOPRANIS, 1957: 9-33. Se ha localizado una legislación similar en esos años en otros concejos castellanos. JARA FUENTE, 21 (Logroño, 1997): 119-134. PUÑAL FERNÁNDEZ, 17 (Madrid, 1994): 185-212.

${ }^{83}$ RUIZ PILARES y BOCHACA, 2016: 7-34.

${ }^{84}$ AZNAR VALLEJO, 2003: 119-120.

${ }^{85}$ Antes de su muerte en 1499, sabemos que andaba en negocios con su también compatriota Bernabé de Moleón, que elevó un pleito en 1503 contra sus hijos a tenor de algunas cuestiones relativas a ellos, ARCHGR, caja 5505. 
Cuadro 1. Exportaciones del jurado Francesco Adorno (1484-1490) ${ }^{86}$

\begin{tabular}{|c|c|c|c|}
\hline Año & Embarcación & Cargamento & Destino \\
\hline 1484 & una carabela & 65 toneladas de vino y fruta & $\begin{array}{c}\text { Honfleur (Normandía) o } \\
\text { Plymouth (Inglaterra) }\end{array}$ \\
\hline 1484 & una nao & vino y fruta & $\begin{array}{c}\text { Ruan (Normandía) o Plymouth } \\
\text { (Inglaterra) }\end{array}$ \\
\hline 1490 & una o dos naos & vino y fruta & Flandes \\
\hline 1490 & no se indica & vino y fruta & Inglaterra \\
\hline
\end{tabular}

Francesco aprovechaba el viaje de vuelta de sus navíos para atestar sus bodegas de cuero y paños de esos mercados, productos que alcanzaban buenos precios en el mercado jerezano ${ }^{87}$ : en 1490 el trapero local Diego de Navarrete le pagó 129.000 por «ciertos lienzos» flamencos e ingleses ${ }^{88}$. Estos paños eran muy demandados por los artesanos locales y las familias más acomodadas de la ciudad (cuadro 2). Este género también le servía para pagar los servicios de los maestres de las embarcaciones, evitando así el uso de moneda ${ }^{89}$. No eran los únicos lienzos con los que mercadeaba. En 1490 invirtió la significativa cantidad de 425.000 maravedíes en la compra de 3.724 varas de paño toledano. Parte de la mercancía fue pagada proporcionando alumbre a estos comerciantes castellanos ${ }^{90}$.

${ }^{86}$ AHPNJF, 1484, escribano Hernando de Carmona, ff. 241 y 247v; 1490, escribano Juan de Ortega, ff. 39v y 166r.

${ }^{87}$ MINGORANCE RUIZ, 2013: 1055-1057. También se solía importar estaño o cobre, BELLO LEÓN, 1995: 74. Esta práctica a la inversa, vender tejidos para posteriormente comprar productos locales - vino principalmente- ha sido descrita para el caso de los mercaderes bretones en RUIZ PILARES, BOCHACA: 2016: 7-34.

${ }_{88}$ AHPNJF, 1484, escribano Hernando de Carmona, f. 199r.

${ }^{89}$ En 1484 pagó al maestre Peláez con ciertos paños, AHPNJF, 1484, escribano Hernando de Carmona, f. 258v.

${ }^{90}$ AHPNJF, 1490, escribano Bartolomé de Maya, f. 359v; 1491, escribano Juan de Ortega, f. $148 \mathrm{v}$. 
CuAdro 2. Negocios del jurado Francesco Adorno (1483-1490) ${ }^{91}$

\begin{tabular}{|c|c|c|c|}
\hline Año & Comprador & Producto & Precio (maravedíes) \\
\hline 1483 & Alonso de Cea, lencero jerezano & Ciertos lienzos & 76.900 \\
\hline 1484 & $\begin{array}{l}\text { Beltrán de León, hermano del } \\
\text { Marqués }\end{array}$ & Cierta ropa & 5.000 \\
\hline 1484 & $\begin{array}{l}\text { Cristóbal Peláez, vecino de El } \\
\text { Puerto }\end{array}$ & Ciertos lienzos & 4.000 \\
\hline 1484 & Batista, curtidor genovés & Ciertas pieles & 6.548 \\
\hline 1490 & $\begin{array}{l}\text { Diego de Navarrete, trapero } \\
\text { jerezano }\end{array}$ & Ciertos lienzos & 129.000 \\
\hline 1491 & Juan Griego, cuchillero jerezano & 7 libras de acero & 5.505 \\
\hline 1491 & Un trapero de Toledo & $\begin{array}{c}500 \text { quintales de } \\
\text { alumbre }\end{array}$ & No se indica \\
\hline Año & Vendedor & Producto & Cantidad (maravedíes) \\
\hline 1490 & $\begin{array}{l}\text { Álvaro Fernández, } \\
\text { trapero de Toledo }\end{array}$ & 133 piezas de paño & 425.000 \\
\hline
\end{tabular}

\section{La inversión en propiedades agrícolas}

La estrategia de ascenso sociopolítico llevada a cabo por el jurado Adorno no se puede entender sin la inversión de buena parte del capital atesorado gracias a las actividades comerciales y crediticias en la compra de tierras en Jerez y su comarca. Esta práctica, más allá de proporcionarle beneficios muy ventajosos para abaratar costes a la hora de adquirir el cargamento que destinaba a los mercados extranjeros, le convirtió en uno de los principales terratenientes de la ciudad, elemento definidor del grupo caballeresco dirigente ${ }^{92}$. Este tipo de propiedades simbolizaban la autorreproducción de su mentalidad fronteriza y caballeresca: «Es casi inevitable una asociación de ideas entre nobleza y la posesión del espacio agrícola», elementos fundamentales para perpetuarse en la cúspide de su sociedad política ${ }^{93}$. Ello explica que las legase en su gran

${ }^{91}$ AHPNJF, 1484, escribano Hernando de Carmona, f. 131r; 1491, escribano Juan de Ortega, f. 148v. MINGORANCE RUIZ, 2013: 1055-1057.

92 MARTÍN GUTIÉRREZ, 2015: 83-101; 2007: 177-197; 26, (Sevilla, 1999): 280-317. Casos de estudio en SÁNCHEZ SAUS, 18 (Barcelona 1988): 469-486. RUIZ PILARES, 35 (Madrid, 2012): 320-332.

${ }^{93}$ CABRERA SÁNCHEZ, 1998: 155. 
mayoría su hijo primogénito Leonís, en 1499, mediante la fórmula testamentaria del traspaso del tercio y quinto de mejora ${ }^{94}$, costumbre que se consolidó en la ciudad a comienzos del siglo XVI mediante la institución de mayorazgos, con o sin licencia regia - a partir de las Leyes de Toro de 1505-, que fortalecieron la posición de los parientes mayores de los linajes de la élite dirigente ${ }^{95}$.

El cereal era el cultivo más importante para la economía jerezana, dedicándose la mayor parte de la superficie arada de su amplio alfoz a su labranza ${ }^{96}$, lo que convertía a esta comarca en una de las más productivas no solo de Andalucía, sino de todo el reino castellano ${ }^{97}$. Sabemos que Francesco llegó a poseer, en la década de 1490, un mínimo de 260 aranzadas — valoradas en más de 250.000 maravedíes - dedicadas a este cultivo distribuidas por Añina, Cuadrado, Torrox y Guadabajaque, entre los límites territoriales de Jerez y El Puerto de Santa María ${ }^{98}$.

Aunque las tierras de «pan llevar», como se les conocía en la época, eran indispensables para convertir a Francesco en uno de los principales terratenientes de la ciudad, lo que explica también su inversión en una gran dehesa cercana al núcleo urbano - en el arroyo Salado_-, valorada en 300.000 maravedíes, su principal fuente de inversión en las fértiles tierras jerezanas fueron los viñedos, cuyos caldos eran la base de sus exportaciones. Sabemos que contaba, a su muerte, con al menos 55 aranzadas dedicadas a este cultivo en los alrededores de la ciudad — Cabeza del Pelado — ${ }^{99}$. Asimismo, aprovechó su influencia y posición en el concejo para obtener, en 1496, un «pedazo de tierra» de propiedad concejil para construir un bodegón junto al camino de El Puerto, muy cercano a sus tierras de Torrox, el cual le servía como punto de venta y almacén de sus productos ${ }^{100}$.

En menor medida, sabemos que también invirtió en otro cultivo especulativo como el olivo. Se han localizado 8 aranzadas dedicadas a este cultivo en la llamada Mata del Olivar, al sur del núcleo urbano jerezano. No debe extrañarnos el menor interés de Francesco por este tipo de tierras: la producción de aceite de la comarca jerezana no era competencia para el Aljarafe sevillano, región olivarera por excelencia de la costa atlántica andaluza ${ }^{101}$.

94 AHPNJF, 1521, escribano Rodrigo de Cuenca, f. 175v.

95 RUIZ PILARES, 35 (Madrid, 2012): 318-322.

${ }^{96}$ MARTÍN GUTIÉRREZ, 2004: 51-53.

${ }^{97}$ La comarca jerezana producía en torno al 20\% del cereal del Reino de Sevilla, LADERO QUESADA y GONZÁLEZ JIMÉNEZ, 1979.

${ }_{98}$ MINGORANCE RUIZ, 2013: 1647-1651. Para la localización y análisis de las propiedades agropecuarias nos remitimos a la cartografía y estudios de MARTÍN GUTIÉRREZ, 2004: 137-214; 2015: 196-202.

99 MINGORANCE RUIZ, 2013: 1647-1651.

100 AMJF, AC, 1496, f. 107r.

101 MARTÍN GUTIÉRREZ, 2007: 187-190. OTTE SANDER, 1996: 29-39. 


\section{El mercado inmobiliario urbano}

La élite caballeresca era el grupo social - junto a las instituciones religiosas - con mayor presencia en este tipo de negocios ${ }^{102}$. Los segmentos inferiores de la sociedad apenas contaban con una vivienda y algún taller para realizar sus trabajos, en buena parte alquilados. Las familias dirigentes sacaron rédito a las viviendas que poseían - principalmente por herencia - mediante sistemas de arrendamiento anuales, y, en menos medida, a través de mecanismos más conservadores como la cesión a cambio de censos enfitéuticos. Por el contrario, fue poco habitual que invirtieran en la compra de nuevas propiedades, salvo para ampliar la vivienda principal y en ocasiones excepcionales relacionadas con coyunturas muy concretas, como la persecución de los conversos o la expulsión de los judíos, como también se ha constatado en otros espacios europeos ${ }^{103}$.

Francesco Adorno parece que fue una de las pocas excepciones en Jerez. Aunque no sabemos con exactitud el número de inmuebles urbanos que poseía a su muerte - un mínimo de seis-, estuvo muy interesado en este mercado. Como ejemplo, invirtió 65.000 maravedíes en la compraventa de tres viviendas en 1490 . El mismo día de la operación las entregó en régimen de arrendamiento a cambio de 6.000 maravedíes, rentabilizado en apenas una década la inversión inicial ${ }^{104}$. Más interesante y compleja fue la adquisición de una sexta parte de una casatienda por 7.000 maravedíes en 1491. En esta ocasión también cedió el mismo día del negocio, aunque en este caso en régimen de censo - 1.000 maravedíes anuales - , la propiedad a su antiguo propietario. Siete años después ya estaba amortizada la compra y había obtenido una renta anual perpetua ${ }^{105}$. Es la primera referencia a un préstamo encubierto o venta de rentas en la ciudad a través de inmuebles urbanos que se conoce, práctica que eludía las prohibiciones relacionados con la usura vinculada a las operaciones de crédito ${ }^{106}$. El mecanismo utilizado

102 CABRERA SÁNCHEZ, 1998: 215-242.

103 RUIZ PILARES, 2017: 606. SESMA MUÑOZ, 2007: 442-443. CASADO ALONSO, 2007: 659-660. Por ejemplo, durante el período de la Guerra de los Cien Años, solares e inmuebles destruidos permitieron la inversión a precios reducidos de la élite urbana, LEGUAY, 1989: 153-154.

104 AHPNJF, 1490, escribano Juan de Ortega, f. 155r.

105 AHPNJF, 1491, escribano Juan de Ortega, f. 129v, 1523, escribano Alonso Guarnido, ff. $640 \mathrm{r}-642 \mathrm{r}$.

106 Algunos años después -1506-, el alcaide Juan Núñez de Villavicencio compró la mitad de la morada de Beatriz Alonso para inmediatamente cederla a censo. Si tenemos en cuenta que el empréstito fue de 3.000 maravedíes y el interés anual percibido 500 maravedíes, fue otra maniobra inmobiliaria bastante lucrativa, AHPNJF, 1506, escribano Sebastián Gaitán, ff. 963v-964v. Otro caso constatado fue protagonizado por el jurado Alonso de Cabra. En 1518 adquirió por 30.000 maravedíes una casa en San Miguel tras la muerte de su propietario, el alférez Gómez Suárez. Posteriormente, la entregó a censo al hijo de su antiguo dueño por 3.000 maravedíes, AHPNJF, 1518, escribano Luis de Llanos, ff. 664r-666v. Sobre la tipología de los censos Rodríguez de Diego, XXXII (Murcia, 1982): 293-306. Para el caso jerezano, este 
era una venta ficticia ${ }^{107}$. El prestamista aparentemente compraba un inmueble a su acreedor para cederlo inmediatamente a censo a su antiguo dueño. Esta renta representaba los intereses anuales que debía resarcir el deudor, solo redimible con la devolución del préstamo originario. Una hipoteca perpetua en muchos casos, a tenor de los escasos ejemplos de préstamos redimidos que se conocen. Este tipo de negocios, conocidos como censos consignativos en la documentación castellana y portuguesa ${ }^{108}$, documentados en otras regiones de Europa desde el siglo XIII - Italia, Francia o la Corona de Aragón ${ }^{109}$ _, no parece que alcanzasen gran difusión en Andalucía hasta principios del siglo XVI ${ }^{110}$.

\section{LA CONSOLIDACIÓN DE LA INTEGRACIÓN EN EL GRUPO DIRIGENTE}

A finales del siglo $\mathrm{XV}$, cuando los Adorno se incorporaron al grupo dirigente, prácticamente se había producido su cierre y consolidación, siendo muy limitados los procesos de ascenso social a partir de esas fechas. Este cerramiento de la élite concejil se asentó en varios pilares fundamentales. Por un lado, el control de los principales oficios de gobierno, que, a mediados del siglo XVI, pasaron de ser vitalicios a convertirse jurídicamente en hereditarios ${ }^{11}$. Por otro, la consolidación de importantes patrimonios inmuebles que, dentro de lo posible, consolidasen por vía de primogenitura mediante vínculos y mayorazgos ${ }^{112}$. A estos elementos se le unía toda una serie de elementos de prestigio que eran fundamentales para reforzar la posición alcanzada, entre los que destacaban la construcción de casas principales a la altura del lugar alcanzado en la cúspide social, la institución de suntuosos enterramientos y capellanías para su mantenimiento, o el reconocimiento de la hidalguía. Sobre estos aspectos nos detendremos en el siguiente epígrafe.

\section{Las casas principales}

La vivienda del cabeza de familia — al igual que ocurría con el apellidoera un elemento de cohesión cargado de simbolismo en las sociedades medievales $^{113}$. En palabras de Sánchez Saus:

tipo de cuestiones fueron planteadas, al analizar el papel de las mujeres en la administración de los bienes inmuebles urbanos, por PÉREZ GONZÁLEZ, 2014: 297-303.

107 SÁITA, 1997: 147-149.

108 BRITO DE ALMEIDA, 1961.

109 IRADIEL MURUGARREN, 2007: 408. GARCÍA MANSILLA, 2002: 14. LEGUAY, 1989: 169-170.

110 BORRERO FERNÁNDEZ, 1986: 230.

111 RUIZ PILARES, 2014: 65-85.

112 RUIZ PILARES, 35 (Madrid, 2012): 321-322.

113 SESMA MUÑOZ, 2007: 442-443. 
... no es sólo una residencia, sino también punto de encuentro de parientes y allegados, ágora donde se discuten todos los temas, desde los más frívolos a los más graves, y oficina desde donde se despachan todos los negocios familiares, servidores, vasallos, amigos, etc. ${ }^{114}$

Desde finales del siglo XV, en Jerez de la Frontera, como venía ocurriendo en las ciudades y villas castellanas a imagen y semejanza de Italia o Flandes, las moradas de los parientes mayores de los principales linajes empezaron a convertirse en auténticas casas-palacio. Estos inmuebles reflejaban, a través de sus destacadas dimensiones, la calidad de los materiales de construcción o los elementos decorativos, la preeminencia social de sus moradores. Asimismo, conectaban al linaje con su barrio o collación, órgano básico de sociabilidad y estructuración política de las ciudades medievales ${ }^{115}$.

En el caso jerezano, la coyuntura económica favorable tras la conquista definitiva del reino de Granada (1492) y el despegue comercial de la región, tras el desarrollo de las rutas del comercio atlántico, fueron clave para que este tipo de viviendas fueran embellecidas y engalanadas con las influencias renacentistas que portaban los mercaderes italianos que llegaban a sus costas. Aunque no se conserva el inmueble de los Adorno, el palacio de los Villacreces ${ }^{116} \mathrm{o}$ de los Lópe $z^{117}$ son algunos ejemplos que aún se conservan de este tipo de arquitectura palaciega. La valoración económica de este tipo de inmuebles oscilaba entre los 90.000-130.000 maravedíes a comienzos del siglo XVI. Un valor que, como mínimo, quintuplicaba el precio de las viviendas de la mayor parte de la población, que rondaba entre los 10.000 y los 20.000 maravedíes $^{118}$. Diferencias y valores similares a los documentados en Sevilla o Córdoba ${ }^{19}$.

Centrándonos en el caso del jurado Francesco Adorno, este personaje adquirió una vivienda en la calle Francos - en su discurrir por la collación de San Marcos-, corazón y vía principal de Jerez, valorada en 96.000 maravedíes ${ }^{120}$. En esos años, la mayor concentración de moradas del grupo dirigente se encontraba a lo largo de esta larga calle que recorría toda la ciudad ${ }^{121}$. Allí se desplazó su hermano Giacomo algunos años después, en 1506, al adquirir una casa, valorada en 100.000 maravedíes, que había pertenecido a un regidor jerezano ${ }^{122}$.

114 SÁNCHEZ SAUS, 1989: 51-52.

115 CROUZET-PAVAN, 1995: 280.

116 LÓPEZ CAMPUZANO, 3 (Madrid, 1991): 39-52.

117 POMAR RODIL y MARISCAL RODRÍGUEZ, 2004: 71-72.

118 RUIZ PILARES, 2017: 590.

119 CABRERA SÁNCHEZ, 1998: 223-224. COLLANTES DE TERÁN SÁNCHEZ, XLVIII/169 (Madrid, 1988): 508-509.

${ }_{120}$ MINGORANCE RUIZ, 2013: 1055-1057.

121 RUIZ PILARES, 2017: 616-617.

122 AHPNJF, 1506, escribano Sebastián Gaitán, f. 559v. 


\section{Los enterramientos y las capellanías}

Otro elemento esencial para consolidar el prestigio y posición familiar fue la construcción de suntuosos enterramientos familiares y capellanías, convirtiendo el rezo en elemento de salvación del alma y memoria del linaje, práctica habitual para estos colectivos para encubrir su ascenso social ${ }^{123}$. Es difícil discernir la línea que separa la devoción por Cristo o la Virgen de la práctica social $^{124}$. A modo de ejemplo, la hija del jurado Francesco, María, participó de las devociones de la Encarnación o la Consolación, muy difundidas en la ciudad, destinando parte de sus bienes a cambio de una serie de misas anuales ${ }^{125}$. En este trabajo nos interesa el análisis de la faceta social de este tipo de manifestaciones religiosas, símbolos de la capacidad económica y el deseo de ostentación social de los grupos dirigentes ${ }^{126}$.

Se ha documentado la erección de dos capillas por parte de esta familia entre finales del siglo XV y la primera mitad del siglo XVI. La primera, situada en la iglesia de San Marcos - y hoy desaparecida - fue instituida por Francesco Adorno con anterioridad a su muerte (1499) ${ }^{127}$. Habrá que esperar a 1537 para que se levante la segunda capilla familiar, obra del reconocido constructor Pedro Hernández de la Zarza a instancias de Giacomo Adorno. Se elevó en el monasterio de Santo Domingo bajo la advocación de la mencionada Virgen de Consolación, llegando hasta nuestros días ${ }^{128}$. Era indispensable dotar económicamente estos enterramientos mediante las llamadas capellanías o beneficios eclesiásticos (cuadro 3), cantidades anuales que sufragaban no solo su edificación, sino su mantenimiento y gastos ineludibles como el salario del capellán, misas, cera, etc.

123 SORIA MESA, 2007: 265-268.

124 MARTÍNEZ GIL, 1996. GARCÍA FERNÁNDEZ, 1996.

125 POMAR RODIL y MARISCAL RODRÍGUEZ, 2014: 35-36. AHPNJF, 1522, escribano Luis de Llanos, f. 526r.

126 YARZA LUACES, 1988: 67-91. ALFONSO SANTORIO, 1997, vol. 1: 193-216. Sobre la religiosidad de los integrantes de la élite jerezana y una breve enumeración de este tipo de fundaciones ver SÁNCHEZ SAUS, 2014: 115-129. GARCÍA GUZMÁN y ABELLÁN PÉREZ, 1916: 61-67. MINGORANCE RUIZ, 68/138 (Madrid, 2016): 541-566.

127 AHPNJF, 1521, escribano Rodrigo de Cuenca, f. 175v.

128 ROMERO BEJARANO y ROMERO MEDINA, 2001: 197-212. 
CuAdro 3. La dotación de la capilla del jurado Francesco Adorno (1506-1538) ${ }^{129}$

\begin{tabular}{|c|c|c|}
\hline Año & Testamentario & Dotación \\
\hline 1506 & $\begin{array}{l}\text { Doña Catalina de Figueroa, } \\
\text { viuda del jurado Francesco } \\
\text { Adorno }\end{array}$ & 10 cahíces de trigo anuales de sus tierras \\
\hline 1521 & $\begin{array}{l}\text { Leonís Adorno, hijo del jurado } \\
\text { Francesco Adorno }\end{array}$ & $\begin{array}{c}\text { 8.700 maravedís de la renta de la dehesa del } \\
\text { Salado }\end{array}$ \\
\hline 1538 & $\begin{array}{l}\text { Francisco Adorno, } \\
\text { veinticuatro. hijo de Leonís } \\
\text { Adorno }\end{array}$ & $\begin{array}{c}\text { Censo de } 1.125 \text { maravedís perpetuos sobre la } \\
\text { mitad de una venta o bodegón camino de El } \\
\text { Puerto de Santa María }\end{array}$ \\
\hline
\end{tabular}

No parece que la capilla de Francesco estuviera especialmente bien servida: tanto Leonís como su hijo Francisco reconocen en sus testamentos que habían desatendido la voluntad del jurado Adorno. Si el primero declaró en 1521 que heredó de su padre el tercio y quinto de sus bienes como mejora testamentaria con cargo de «pagar en cada vn año los maravedís o otras cosas que el capellán oviere de aver e [...] acabar de haser la dicha capilla» ${ }^{130}$, su hijo aún señalaba, en 1538, que «mi padre me dexó çierta mejoría de bienes para que la dicha capilla se hiziese, e no se a hecho» ${ }^{131}$.

\section{La hidalguía}

La condición de hidalgo, en origen, estaba asociada a una categoría militar exenta de impuestos asociada al escalón inferior de la nobleza en los territorios del norte de Castilla. En el proceso de conquistas que se produjeron en Andalucía en el siglo XIII, pasaron a tener unas singularidades que diferenciaron a los poseedores de esta dignidad de sus homólogos norteños ${ }^{132}$. En estas tierras, la condición de hidalgo no conllevó franquicias tributarias, para así evitar que las fortunas más importantes se eximieran de financiar el enfrentamiento con el reino de Granada. Aunque monopolizaron el gobierno de las principales ciudades del reino, como Córdoba o Sevilla, en ciudades de menor entidad, como Jerez, tuvieron que compartirlo con aquellos que atesoraron cierta «cuantía»

129 AHPNJF, 1506, escribano Sebastián Gaitán, f. 588V; 1521, escribano Rodrigo de Cuenca, f. 175v; 1538, escribano Luís de Llanos, f. 163v.

130 AHPNJF, 1521, escribano Rodrigo de Cuenca, f. 175v.

131 AHPNJF, 1538, escribano Luis de Llanos, f. 163r.

132 GERBERT, 1997: 86-90; GERBERT 21 (Buenos Aires, 1980): 78-99. DIAGO HERNANDO, 15 (Madrid, 1992): 31-62. 
para mantener armas y caballo ${ }^{133}$. Para estos, un manifiesto patrimonio agroganadero, el servicio a los señores comarcanos o a la Corona y, sobre todo, el paulatino disfrute de oficios concejiles, les permitió empezar «a confundirse con los nobles [...] de modo que los fueros y privilegios otorgados a ciudades y villas les señalaban un puesto equivalente al de los hidalgos ${ }^{134}$.

La nómina de hidalgos que se elaboró en la ciudad con motivo de la guerra del Rosellón (1494) es el mejor ejemplo de la homogeneidad de estatus social que vino de la mano del control de los resortes del poder a finales del siglo XV: las veinte familias de la «élite concejil» eran consideradas hidalgas. Incluso unos recién llegados como los Adorno - representados en la figura del jurado Francesco-, vieron ennoblecida su sangre a tenor de su influencia social, económica y política ${ }^{135}$. Cuando bien entrado el siglo XVI la mayoría de estas familias se vieron obligadas a certificar su condición hidalga ante la Chancillería de Granada, nadie dudó en testificar en favor de los que venían controlando el gobierno y alardeaban públicamente de su posición desde varias décadas atrás ${ }^{136}$. Así se explica que el bisnieto de Giacomo, Agustín Adorno y Herrera recibiése el título de Caballero de la Orden de Calatrava en $1581^{137}$.

\section{Conclusiones}

La llegada de extranjeros en los momentos finales del Medievo y principios de la Modernidad al Reino de Sevilla es cuestión perfectamente documentada en la historiografía actual. Diversos elementos jugaban a favor de dicho proceso migratorio: expansión demográfica en sus lugares de origen, desigualdades en el acceso a la riqueza económica y a la influencia social y política, dificultades en el comercio con Oriente derivadas del ascenso del poder otomano - hasta llegar a prácticamente cortar esta vía comercial — apertura de las rutas atlánticas que multiplicaron las posibilidades de negocio no ya sólo en la Península Ibérica sino en toda la fachada atlántica. Todo ello se traducirá en una relevante presencia exterior en dicho reino, que incluirá a naturales de muy diversos lugares: Península Itálica, Flandes, Islas Británicas, etc. Entre la destacable colonia procedente de la actual Italia sobresalen, sin lugar a dudas, los ligures.

133 GONZÁLEZ JIMÉNEZ, 2015: 203-232.

134 SÁNCHEZ SAUS, 1996: 112-113.

135 «Llamamiento...», 1991, vol. I: 276-278.

136 SORIA MESA, 2007: 254-260. DÍAZ DE LA GUARDIA Y LÓPEZ, 18 (Madrid, 2005): 148-149.

${ }_{137}$ AHN, OM-Caballeros Calatrava, exp. 22. El árbol genealógico completo de esta rama de los Adorno en RAH, D-34, fol. 191. 
En el Reino de Sevilla destacan, amén de la capital hispalense - auténtico centro dinamizador de la economía castellana de la época- las ciudades del Bajo Guadalquivir: Cádiz, El Puerto de Santa María, Sanlúcar de Barrameda y, por supuesto, Jerez de la Frontera. Desde la conquista de Granada y el alejamiento del peligro de la frontera, las posibilidades de crecimiento económico de la ciudad de Jerez no dejaron de crecer. El asentamiento de caballeros en ella fue, de manera progresiva, siendo sustituido por la presencia de mercaderes, burgueses y aristócratas, lo que, al hilo del aumento de la riqueza, supuso la aparición de nuevos grupos sociales que buscaron en el enriquecimiento la base de su acceso al poder social y político.

Caso paradigmático en este proceso es el representado por la familia genovesa Adorno, cuyo primer personaje - Francesco- apareció por la ciudad en la década de los 70 del siglo XV. Comerciante destacado en multitud de productos y eficiente actor del crédito - cambiador-, fue generando un ingente patrimonio que le permitiría hacerse un hueco en el regimiento de Jerez. Su hijo Leonís aún situaría el listón de su ascenso político más alto al conseguir una veinticuatría. Las relaciones de esta familia Adorno con la casa del marqués de Cádiz y la política de casamientos con miembros de la aristocracia local serían asimismo causa y consecuencia de dicho ascenso económico, social y político. El segundo miembro en importancia de dicho clan sería su hermano Giacomo, quien se mantendría siempre alejado del primer foco de la política, pero que conseguiría otra regiduría para su hijo Agustín. La amplitud y alcance de las numerosas actividades desplegadas por los Adorno les habían permitido el ascenso social y la asunción de roles políticos relevantes en la vida local, que suponían enormes ventajas de todo tipo para quienes las lograban.

En suma, estamos en presencia de unos personajes representantes de la elite económica, social y política de la ciudad de Jerez, que asentaron su enorme influjo en la posesión de extensas fincas en el alfoz jerezano, en sus actividades comerciales y crediticias y que se reflejaría en la suntuosidad de sus inmuebles, enterramientos y capillas. Todo ello en un proceso de retroalimentación basado en su posición económica, social y política y un naciente capitalismo, cuyas posibilidades supieron explotar con sobresaliente éxito.

\section{Bibliografía}

Alfonso Santorio, Paula, «Religiosidad y nobleza. La fundación de capellanías. Un ejemplo malagueño», en Francisco Javier Campos y Fernández de Sevilla (coord.), Religiosidad popular en España, San Lorenzo del Escorial, Real Centro Universitario Escorial-María Cristina, 1997, vol. 1: 193-216.

Ascieri, Andrea, Notizie storiche intorno alla riunione delle famiglie in alberghi in Genova, Génova, Tipografia Faziola, 1846. 
Asenjo González, María, Urban Elites and Aristocratic Behaviour in the Spanish Kingdoms at the End of the Middle Ages, Turnhout (Bélgica), Brepols, 2013.

Aznar Vallejo, Eduardo, «Andalucía y el Atlántico Norte a fines de la Edad Media», Historia. Instituciones. Documentos, 30 (Sevilla, 2003): 103-120.

Baraldi, Giuseppe, Notizia biográfica sul cardinale Ferdinando Maria Saluzzo, Nápoles, Stamperi e cartiere del Fibreno, 1845.

Bello León, Juan Manuel, Extranjeros en Castilla (1474-1501): notas y documentos para el estudio de su presencia en el reino a fines del siglo $X V$, Tenerife, Ed. Los Realejos, 1994.

Bello León, Juan Manuel, «El Reino de Sevilla en el comercio exterior castellano (siglos XIV y XV)», en Hilario Casado Alonso (ed.), Castilla y Europa. Comercio y Mercaderes en los siglos XIV, XV y XVI, Burgos, Diputación provincial de Burgos, 1995: 57-80.

Bello León, Juan Manuel, «Almadrabas andaluzas a finales de la Edad Media. Nuevos datos para su estudio», Historia. Instituciones. Documentos, 32 (Sevilla, 2005): 81-113.

Bello León, Juan Manuel, «La presencia catalana en la Andalucía Occidental a finales de la Edad Media», Anuario de Estudios Medievales, 40/1 (Barcelona, 2010): 93-127.

Bello León, Juan Manuel, «Mercaderes del siglo XV de Jerez de la Frontera», Historia. Instituciones. Documentos, 41 (Sevilla, 2014): 11-44.

Bertelli, Sergio, Il potere oligarchico nello stato-città medievale, Florencia, La nouva Italia, 1978.

Borrero Fernández, Mercedes, La organización del trabajo. De la explotación de la tierra a las relaciones laborales en el campo andaluz (siglos XIII-XVI), Sevilla, Universidad de Sevilla, 2003.

Boucheron, Patrick y Menjot, Denis, «La ville médiévale», en Jean-Luc Pinol (dir.), Histoire de l'Europe urbaine, París, Seuil, 2011, vol. II.

Brito de Almeida, Mario Julio, Raices do censo consignativo. Para a história do crédito medieval portugués, Coimbra, Atlàntida, 1961.

Cabrera Sánchez, Margarita, Nobleza, oligarquía y poder en Córdoba al final de la Edad Media, Córdoba, Universidad de Córdoba/Obra Social y Cultural de Cajasur, 1998.

Carmona Ruiz, María Antonia y Martín Gutiérrez, Emilio, Recopilación de las ordenanzas del Concejo de Xerez de la Frontera. Siglos XV-XVI: Estudio y edición, Cádiz, Universidad de Cádiz, 2010.

Casado Alonso, H., «Crecimiento urbano y mercado inmobiliario en Burgos en el siglo XV», en Mercado inmobiliario y paisajes urbanos en el occidente europeo (siglos XI-XV), Pamplona, Gobierno de Navarra, 2007: 631-689.

Chiavari Cattaneo della Volta, Elena, Adorno: Adornes, Génova, Asociazione nobiliare della Liguria, 2002.

Collantes de Terán Sánchez, Antonio, «Propiedad y mercado inmobiliario en la Edad Media: Sevilla, Siglos XIII-XVI», Hispania, XLVIII/169 (Madrid, 1988): 493-527.

Corte-Real, Manuel Henrique, A feitoria portuguesa na Andaluzia (1500-1532), Lisboa, Instituto de Alta Cultura, 1967.

Crouzet-Pavan, Elisabeth, «Le marché immobilier vénitien au Moyen Âge: entre necessites économiques et logiques anthropologiques», en Olivier Faron y Étienne 
Hubert (coords.), Le sol et l'inmmeuble: les formes dissociées de proprieté immobilière dans les villes de France et d'Italie (XIIe-XIXe siècle), Roma, École française de Rome, 1995: 269-300.

D’Arienzo, Luisa, «Le colonie genovesi di Siviglia, Cadice, Jerez de la Frontera e Puerto de Santa María alla vigilia del viaggio di scoperta colombiano attraverso una fonte fiscale sulla guerra di Granada (l'assedio di Baza del 1489)», en Luisa D’Arienzo (ed.), Sardegna, Mediterraneo e Atlantico tra Medioevo e Età Moderna, Roma, Bulzoni, 1993, vol. 3: 133-183.

Díaz de la Guardia y López, Luis, «El poder feudal como origen de hidalguía en la Baja Edad Media castellana: un ejemplo del señorío de Villena», Espacio, Tiempo y Forma, Serie III, Historia Medieval, 18 (Madrid, 2005): 129-168.

Epstein, Steven A., Genoa \& Genoese, 958-1528, Chapel Hill, University of North Carolina, 1996.

Fábregas García, Adela, Un mercader genovés en el reino de Granada. El libro de cuentas de Agostino Spinola (1441-1447), Granada, Universidad de Granada, 2002.

Franco Silva, Alfonso y Cruz Mariño, Rafael, «Juan Pacheco, privado de Enrique IV, y el oficio del Corregidor de Jerez de la Frontera», En la España Medieval, 35 (Madrid, 2012): 285-316.

García Fernández, Manuel, Los castellanos y la muerte. Religiosidad y comportamientos colectivos en el Antiguo Régimen, Valladolid, Junta de Castilla-León, 1996.

García Guzmán, María del Mar y Abellán Pérez, Juan, La religiosidad de los jerezanos según sus testamentos (siglo XV), Cádiz, Libros EPCCM, 2016.

García Mansilla, Juan Vicente, Vivir a crédito en la Valencia medieval: de los orígenes del sistema censal al endeudamiento del municipio, Valencia, Universidad de Valencia, 2002.

Gerbert, Marie-Claude, La noblesse dans le Royaume de Castille. Etude sur ses structures sociales en Estrémadure (1454-1516), París, La Sorbonne, 1979.

Gerbert, Marie-Claude, «La population noble dans le Royaume de Castille vers 1500. La repartition géographique de ses différentes composantes», Anales de Historia Antigua y Medieval, 21 (Buenos Aires, 1980): 78-99.

Gerbert, Marie-Claude, Las noblezas españolas en la Edad Media. Siglos XI-XV, Madrid, Alianza Editorial, 1997.

Girón Pascual, Rafael María, Las Indias de Génova: Mercaderes genoveses en el Reino de Granada durante la Edad Moderna (ss. XVI-XVIII), Granada, Universidad de Granada, 2012, disponible en: http://digibug.ugr.es/handle/10481/25160 [consultado el 22 de abril de 2019].

Girón Pascual, Rafael María, «Exogamia, endogamia e ilegitimidad: estrategias familiares de los mercaderes genoveses de Granada durante la Edad Moderna (ss. XVI-XVII)», Historia y Genealogía, 3 (Córdoba, 2013): 83-98.

González Arévalo, Raúl, «Exilio, diversificación y superación. Estrategias de supervivencia de los Spínola de Granada ante la guerra final de conquista (1481-1492)», Reti Medievali Rivista, 15/2 (2013): 1-22.

González Arévalo, Raúl, «Presencia diferencial italiana en el sur de la Península Ibérica en la Baja Edad Media. Estado de la cuestión y propuesta de investigación», Medievalismo, 23 (Madrid, 2013): 175-208. 
González Arévalo, Raúl, «Integración y movilidad social de las naciones italianas en la Corona de Castilla: genoveses, florentinos y venecianos en la Andalucía bajomedieval», en Lorenzo Tanzini y Sergio Tognetti (coords.), La mobilità sociale nel Medioevo italiano. Competenze, conoscense e saperi tra professioni e ruoli social (secc. XII-XV), Roma, Viella, 2016a: 375-401.

González Arévalo, Raúl, «La integración de los italianos en las sociedades portuarias andaluzas (siglos XIII-XV)», en Jesús Ángel Solórzano Telechea, Beatriz Arízaga Bolumburu y Michel Bochaca (coords.), Las sociedades portuarias de la Europa Atlántica en la Edad Media, Logroño, Instituto de Estudios Riojanos, 2016b: 249-273.

González Gómez, Antonio, «La población de Jerez de la Frontera en el siglo XV», en I coloquio de Historia Medieval Andaluza, Córdoba, Monte de Piedad y Caja de Ahorros de Córdoba, 1982: 35-47.

González Jiménez, Manuel, «La caballería popular en Andalucía (siglos XIII al XV)», en Manuel González Jiménez, Andalucía a debate y otros estudios, Sevilla, Universidad de Sevilla, 2015: 203-232.

González Zalacaín, Roberto y Gómez Muñoz, Víctor, «Jerez y el Mar en la Baja Edad Media», en José Sánchez Herrero y Manuel González Jiménez (dirs.), 750 aniversario de la incorporación de Jerez a la Corona de Castilla: 1264-2014, Jerez de la Frontera, Ayuntamiento de Jerez de la Frontera, 2014: 351-372.

Guerrero Navarrete, Yolanda, «Poder patricio e identidad política en Burgos», Anales de la Universidad de Alicante. Historia Medieval, 16 (Alicante, 2009-2010): 63-91.

Heers, Jacques, «Los genoveses en la sociedad andaluza del siglo XV: orígenes, grupos, solidaridades», en Actas del II Coloquio de Historia Medieval Andaluza, Sevilla, Diputación Provincial de Sevilla, 1982: 419-444.

Iradiel Murugarren, Paulino, «Mercado inmobiliario, crédito y crecimiento urbano medieval en Valencia», en Mercado inmobiliario y paisajes urbanos en el occidente europeo (siglos XI-XV), Pamplona, Gobierno de Navarra, 2007: 377-416.

Jara Fuente, José Antonio, «Élites urbanas: las políticas comerciales y de mercado como formas de prevención de conflictos y de legitimación del poder (La veda del vino en Cuenca en la Baja Edad Media)», Brocar: Cuadernos de investigación histórica, 21 (Logroño, 1997): 119-134.

Ladero Quesada, Miguel Ángel, «Unas cuentas en Cádiz (1485-1486)», Cuadernos de Estudios Medievales, II-III, (Cádiz, 1975): 85-120.

Ladero Quesada, Miguel Ángel, «Corona y ciudades en la Castilla del siglo XV», En la España Medieval, 5 (Madrid, 1986): 551-574.

Ladero Quesada, Miguel Ángel y González Jiménez, Manuel, Diezmo eclesiástico y producción de cereales en el reino de Sevilla (1408-1503), Sevilla, Universidad de Sevilla, 1979.

Leguay, Jean-Pierre, «La propriété et le marché de l'immobilier à la fin du Moyen Âge dans le royaume de France et dans les grands fiefs», en D'une ville à l'autre. Structures matérielles et organisation de l'espace dans les villes européennes (XIIIe- $X$ VIe Siècle), Roma, École française de Rome, 1989: 135-199.

Leverotti, Franca, Famiglia e istituzioni nel Medioevo italiano, Roma, Carocci, 2005.

Litta, Pompeo, Famiglie celebri d'Italia. Adorno di Genova [en línea], Milán, 1849, vol. I, disponible en: http:/gallica.bnf.fr/ark:/12148/btvlb8452316z/f2.image.r=adorno [consultado el 10 de junio de 2017].

Hispania, 2019, vol. LXXIX, nº 263, septiembre-diciembre, págs. 669-698, ISSN: 0018-2141, e-ISSN: 1988-8368 https://doi.org/10.3989/hispania.2019.016 
«Llamamiento que hicieron los señores Reyes Católicos Don Fernando y Doña Isabel, año de mil y cuatrocientos y novena y cuatro, a los caballeros hijodalgo en su Corte para la marcha al Rosellón», en Anales de la Real Academia Matritense de Heráldica y Genealogía, Madrid, Real Academia Matritense, 1991, vol. I: 276-278.

López Campuzano, Julia, «La casa-palacio de los Ponce de León en Jerez de la Frontera», Anales de Historia del Arte, 3 (Madrid, 1991-1992): 39-52.

López de Coca Castañer, José Enrique y López Beltrán, María Teresa, «Mercaderes genoveses en Málaga (1487-1516). Los hermanos Centurión e Ytalian», Historia. Instituciones. Documentos, 7 (Sevilla, 1980): 95-123.

Martín Gutiérrez, Emilio, «Los contratos de siega en Jerez de la Frontera en la Baja Edad Media», Historia. Instituciones. Documentos, 26 (Sevilla, 1999): 280-317.

Martín Gutiérrez, Emilio, La organización del paisaje rural en la Baja Edad Media, Sevilla, Universidad de Cádiz, 2004.

Martín Gutiérrez, Emilio, «Nuevos datos sobre la población y los genoveses en la ciudad de Cádiz. Una relectura del padrón de vecinos de 1467», En la España Medieval, 29 (Madrid, 2006): 187-223.

Martín Gutiérrez, Emilio, «Poder, paisaje, estructura de la propiedad y sistemas de explotación: las tierras del olivar en Jerez de la Frontera durante el siglo XV y el primer cuarto del XVI», en I Congreso de la Cultura del Olivo, Jaén, Instituto de Estudios Giennenses, 2007: 177-198.

Martín Gutiérrez, Emilio, «El viñedo en la zona de Jerez a finales de la Edad Media», en Antonio Malpica Cuello, Rafael Peinado Santaella y Adela Fábregas García (eds.), Historia de Andalucía. VII Coloquio, Granada, Universidad de Granada, 2009: 287-300.

Martín Gutiérrez, Emilio, Paisajes, ganadería y medio ambiente en las comarcas gaditanas. Siglos XIII al XVI, Cádiz, Universidad de Cádiz/Universidad de Extremadura, 2015.

Martínez Gil, Francisco, La muerte vivida: muerte y sociedad en Castilla durante la Baja Edad Media, Madrid, Universidad de Castilla la Mancha, 1996.

Mingorance Ruiz, José Antonio, Los extranjeros en Jerez de la Frontera a fines de la Edad Media, tesis doctoral, Universidad Pablo de Olavide de Sevilla, 2013, disponible en: http://hdl.handle.net/10433/755 [consultado el 10 de septiembre de 2018].

Monsalvo Antón, José María, El sistema político concejil: el ejemplo del señorío de Alba de Tormes y su concejo de villa y tierra, Salamanca, Universidad de Salamanca, 1988.

Monsalvo Antón, José María, «La participación política de los pecheros en los municipios castellanos de la Baja Edad Media. Aspectos organizativos», Studia Historica. Historia Medieval, VII (Salamanca, 1989): 37-93.

Monsalvo Antón, José María, «La sociedad política en los concejos castellanos de la meseta durante la época del regimiento medieval. La distribución social del poder», en Concejos y ciudades en la Edad Media hispánica, Ávila/León, Fundación Sánchez Albornoz, 1990: 357-428.

Monsalvo Antón, José María, «Parentesco y sistema concejil. Observaciones sobre la funcionalidad política de los linajes urbanos en Castilla y León (siglos XII-XV)», Hispania, 53/185 (Madrid, 1993): 937-969. 
Monsalvo Antón, José María, «Torres, tierras, linajes. Mentalidad social de los caballeros urbanos y de la élite dirigente en la Salamanca medieval (siglos XIII-XV)», en José María Monsalvo Antón (ed.), Sociedad urbanas y culturas políticas en la Baja Edad Media castellana, Salamanca, Universidad de Salamanca, 2013: 165-230.

Musso, Riccardo, «I “colori delle Riviere”. Fazioni politiche e familiari a Genova e nel suo dominio tra XV e XVI secolo», en Marco Gentile, Guelfi e Ghibellini nell'età del Rinascimento, Roma, Viella, 2005: 523-561.

Otte Sander, Enrique, Sevilla y sus mercaderes a fines de la Edad Media, Sevilla, Fundación El Monte, 1996.

Pagani, Gianluca, «Genova, la Península Ibérica en el Mediterraneo del siglo XIII. Entre economía y política», en Diogo Faria y Filipa Lopes (coords.), Incipit 3. Workshop de Estudos Medievais, Oporto, Universidad de Oporto, 2015: 43-52.

Palencia, Alonso de, Crónica de Enrique IV, traducción e introducción por Antonio Paz y Meliá, Madrid, Atlas, 1974.

Pérez González, Silvia, «Las mujeres de la muy noble y muy leal ciudad de Jerez de la Frontera: siglos XII-XV», en José Sánchez Herrero y Manuel González Jiménez (coords.), 750 aniversario de la incorporación de Jerez a la Corona de Castilla: 1264-2014, Jerez de la Frontera, Ayuntamiento de Jerez de la Frontera, 2014: 287-305.

Petti Balbi, Giovanna, Simon Boccanegra e la Genova del Trecento, Génova, Edizioni Scientifiche Italiane, 1991a: 218-223.

Petti Balbi, Giovanna, Una città e il suo mare. Genova nel medioevo, Bologna, Ed. Bruno Mondadori, 1991b.

Petti Balbi, Giovanna, Mercanti e nationes nelle Fiandre: i genovesi in età bassomedievale, Pisa, Gisem edizioni, 1996: 21-46.

Pomar Rodil, Pablo Javier y Mariscal Rodríguez, Miguel Ángel, Jerez artística y monumental, Madrid, Sílex, 2004.

Rodríguez de Diego, José Luis, «Hacia una catalogación y mecanización de un importante fondo documental: los censos», Boletín de la ANABAD, XXXII (Murcia, 1982): 293-306.

Romero Bejarano, Manuel y Romero Medina, Raúl, «Pedro Fernández de la Zarza: un maestro tardogótico de la Baja Andalucía (1494-1569)», en Begoña Alonso Ruiz (coord.), La arquitectura tardogótica castellana en Europa y América, Madrid, Editorial Sílex, 2011: 197-212.

Ríos Toledano, Daniel, «Apud Cadesse: Paisaje Marítimo y Navegación genovesa en el puerto de Cádiz en el siglo XIII», Riparia, 2. ${ }^{\circ}$ suplemento (Cádiz, 2019): 81-111.

Rucquoi, Adeline, «Las oligarquías urbanas y las primeras burguesías en Castilla», en Luis Antonio Ribot García, Adolfo Carrasco Martínez y Luis Adao da Fonseca (coords.), El Tratado de Tordesillas y su época, Salamanca, Junta de Castilla y León, 1994, vol. I: 345-369.

Ruiz Pilares, Enrique José, «El mayorazgo del veinticuatro Pedro Camacho "el Rico" (1507). El patrimonio del caballero más acaudalado de su tiempo», En la España Medieval, 35 (Madrid, 2012): 317-347.

Ruiz Pilares, Enrique José, «La sociedad jerezana y su implicación en las actividades comerciales. La producción y la comercialización del vino (finales s. XV-inicios s.

Hispania, 2019, vol. LXXIX, nº 263, septiembre-diciembre, págs. 669-698, ISSN: 0018-2141, e-ISSN: 1988-8368

https://doi.org/10.3989/hispania.2019.016 
XVI)», en Jesús Ángel Solórzano Telechea, Beatriz Arízaga Bolumburu y Michel Bochaca (coords.), Las sociedades portuarias de la Europa Atlántica en la Edad Media, Logroño, Instituto de Estudios Riojanos, 2016: 337-364.

Ruiz Pilares, Enrique José, El poder en el concejo de Jerez de la Frontera durante el reinado de los Reyes Católicos (1474-1504): espacios, ámbitos y recursos, tesis doctoral inédita, Universidad de Cádiz, 2017.

Ruiz Pilares, Enrique José y Bochaca, Michel, «Un exemple de relations commerciales entre le pays de León et l'Andalousie au debut du XVIe siécle, d'après le compte d'un marchand de Morlaix», Annales de Bretagne et des Pays de l'Ouest, 123/4 (Rennes, 2016): 7-34.

Sáita, Eleonora, Case e mercato immobiliare a Milano in età visconteo-sforzesca (secoli XIV-XV), Milán, CUEM, 1997.

Sánchez Herrero, José, Cádiz, la ciudad medieval y cristiana (1260-1525), Córdoba, Monte de Piedad y Caja de Ahorros de Córdoba, 1986.

Sánchez Saus, Rafael, «De los patrimonios nobiliarios en la Andalucía del siglo XV: los bienes del caballero jerezano Martín Dávila (1502)», Anuario de Estudios Medievales, 18 (Barcelona, 1988): 469-486.

Sánchez Saus, Rafael, Caballería y linaje en la Sevilla medieval, Cádiz, Universidad de Cádiz/Diputación de Sevilla, 1989.

Sánchez Saus, Rafael, Linajes sevillanos medievales, Sevilla, Ediciones Guadalquivir, Sevilla, 1991.

Sánchez Saus, Rafael, Linajes medievales de Jerez de la Frontera, Sevilla, Ediciones Guadalquivir, 1996.

Sánchez Saus, Rafael, Las élites políticas bajo los Trastámara: poder y sociedad en la Sevilla del siglo XIV, Sevilla, Universidad de Sevilla, 2009.

Sánchez Saus, Rafael, «La religiosidad de los jerezanos», en Javier Enrique Jiménez López de Eguileta y Pablo Javier Pomar Rodil (coords.), Limes fidei. 750 años del cristianismo en Jerez, Jerez de la Frontera, Diócesis de Asidonia-Jerez, 2014: 115-129.

Sancho de Sopranis, Hipólito, «Los genoveses en la región gaditano-xericense de 1460 a 1800», Hispania, VIII (Madrid, 1948): 353-402.

Sancho de Sopranis, Hipólito, Documentos para la Historia del vino, Jerez de la Frontera, Junta Oficial de la Fiesta de la Vendimia Jerezana, 1957.

Sesma Muñoz, José Ángel, «Mercado inmobiliario en Zaragoza (1370-1420). La reorganización urbana bajomedieval», en Mercado inmobiliario y paisajes urbanos en el occidente europeo (siglos XI-XV), Pamplona, Gobierno de Navarra, 2007: 417-470.

Soria Mesa, Enrique, La nobleza en la España moderna: cambio y continuidad, Madrid, Marcial Pons, 2007.

Soria Mesa, Enrique, «Poder Local y estrategias matrimoniales. Los genoveses en el reino de Granada (ss. XVI y XVII)», en Manuel Herrero Sánchez, Yasmina Rocío Ben Yessef Garfia, Carlo Bitossi y Dino Puncuh (coords.), Génova y la monarquía hispánica (1528-1713), Génova, Società Ligure di Storia Patria, 2011: 21-46.

Tomas y Valiente, Francisco, «Origen bajomedieval de la patrimonialización y la enajenación de oficios públicos en Castilla», en Actas del I Simposium de Historia de la Administración, Madrid, Instituto de Estudios Administrativos, 1970: 125-159. 
Trapero Fernández, Pedro, «Roman viticulture analysis based on Latin agronomits and the application of a geographic information system in lower Guadalquivir», Virtual Archeology Review, 14 (Valencia, 2016): 53-60.

Val Valdivieso, M. ${ }^{\mathrm{a}}$ Isabel del, «Ascenso social y lucha por el poder en las ciudades castellanas del siglo XV», En la España Medieval, 17 (Madrid, 1994): 157-184.

Valdeón Baruque, Julio, «Las oligarquías urbanas», en Concejos y ciudades en la Edad Media hispánica, Ávila/León, Fundación Sánchez Albornoz, 1990: 507-536.

Vaquero Piñeiro, Manuel, «I censi consegnativi. La vendita delle rendite in Italia nella prima Età Moderna», Rivista di storia dell'agricoltura, 47/1 (Firenze, 2007): 57-94.

Yarza Luaces, Joaquín, «La capilla funeraria hispana en torno a 1400», en Manuel Núñez Rodríguez y Emelindo Portela Silva (coords.), La idea y el sentimiento de la muerte en la historia y el arte de la Edad Media, Santiago de Compostela, Universidad de Santiago de Compostela, 1988: 67-91.

Recibido: 28/09/2018

Aceptado: 07/05/2019 